\title{
Green Square Town Centre: the making of a sustainable town centre in a city
}

\author{
D. A. White \\ The Council of the City of Sydney, Australia
}

\begin{abstract}
Green Square is a major urban renewal project by the City of Sydney which will transform an older industrial area (80 hectares) into a major centre comprising residential, employment, and community uses and open space. The Green Square project forms part of a key objective in Sustainable Sydney 2030 to provide an additional population of 40,000 people and 20,000 jobs by 2030 . The city is providing a new town centre that also contributes to a sustainable Sydney in accordance with Sustainable Sydney 2030.

The paper investigates the past and present challenges in providing a new town centre within an existing urban area and how these have been overcome. Challenges include flooding, traffic and transport, infrastructure funding, fragmented land ownerships, climate change and place making. The paper identifies and appraises the various planning mechanisms that were applied to encourage developers and the state government to partner in the city's vision. These include planning agreements, town centre plans; development rights schemes, infrastructure measures and working with government.

This paper identifies how the city is contributing to the renewal process by developing sustainable infrastructure, implementing water recycling, civic buildings and introducing place making initiatives to transform Green Square into a vibrant area to live and work.
\end{abstract}

Keywords: city, sustainability, redevelopment, renewal, government.

\section{Introduction}

Cities never remain static - they are constantly changing due to social, cultural, economic and sometimes even physical issues. From its evolution as a penal colony in 1788 , Sydney has never stopped growing. Population growth has largely 
occurred due to immigration firstly from the United Kingdom but later as different European and Asian cultures came to Australia. A recent rise in the natural birth rate also has increased Sydney's population. Currently half of Sydney's population was born overseas and more than a third speak a language other than English at home.

Sydney has a population of 4.7 million people spread out over an area of 12,000 square kilometres which spans out from the Tasman Sea to National Parks in the north, south and west. The Sydney Region or Cumberland Plain is now characterised by a sprawling mass of urban development punctuated by major centres connected by major radial railways and roads as well as areas of green space and waterway (refer to Figure 1).

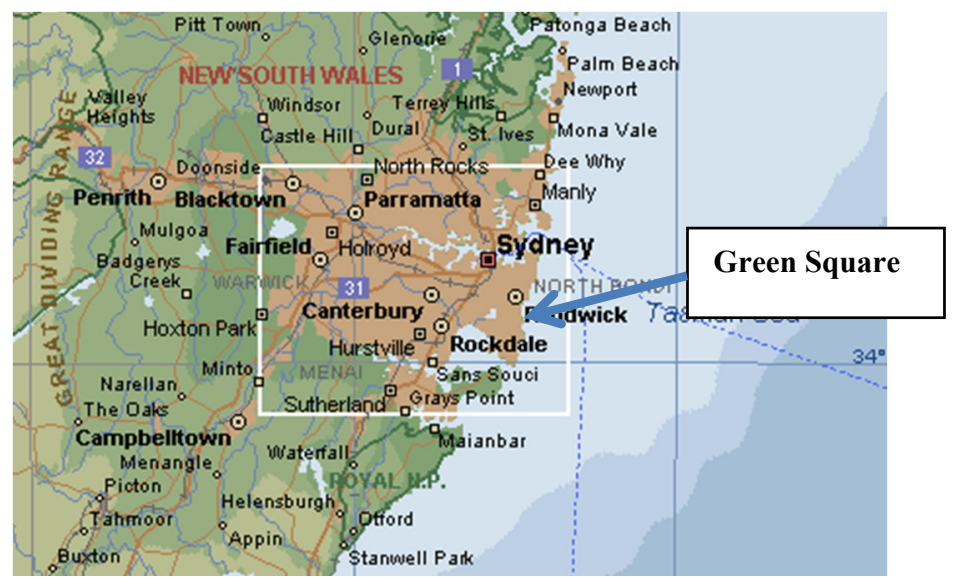

Figure 1: $\quad$ Map of the Sydney region [1].

Typically the state government has been responsible for planning and providing the major infrastructure to service urban areas. This has occurred against the backdrop of a number of metropolitan city plans and strategies such as the County of Cumberland Planning Scheme 1951, Sydney Region Outline Plan 1968 and more recently the City of Cities 2006 and Draft Metropolitan Strategy for Sydney 2013.

The role of local government is to implement the metropolitan strategic plans as well as to provide the key human services such as waste management and provision of local roads, and community facilities and open space for the population.

It is a constant challenge for both State and local government to match service provision with a constantly changing demographic and cultural profile.

Originally metropolitan planning in Sydney focused on greenfield release areas at the city's fringe which would be connected by roads and railways. As the demography changed and the demand to live closer to work became apparent, the State government began to implement urban consolidation from about the 
1980s which focused on providing new housing and employment in existing areas or at "brownfield sites".

This lead to the development of large regional centres such as Parramatta, which is now Sydney's second largest CBD, Liverpool which services the south west, Chatswood to the north and Hurstville to the south. To achieve urban consolidation, local government has a key role in planning for housing for their own areas but also for the wider Sydney region. Development of a number of high density mixed-use centres such as Burwood, Bankstown and Hornsby, along the Sydney's main rail lines reflects the urban consolidation strategy (refer to Figure 2).

Green Square is an inner city area also located near the airport, is the City of Sydney's response to achieving urban consolidation. Green Square is nominated as a "planned major centre" that will have a future population of 40,000 people and a workforce of 20,000 by 2030 (refer to Figure 2).

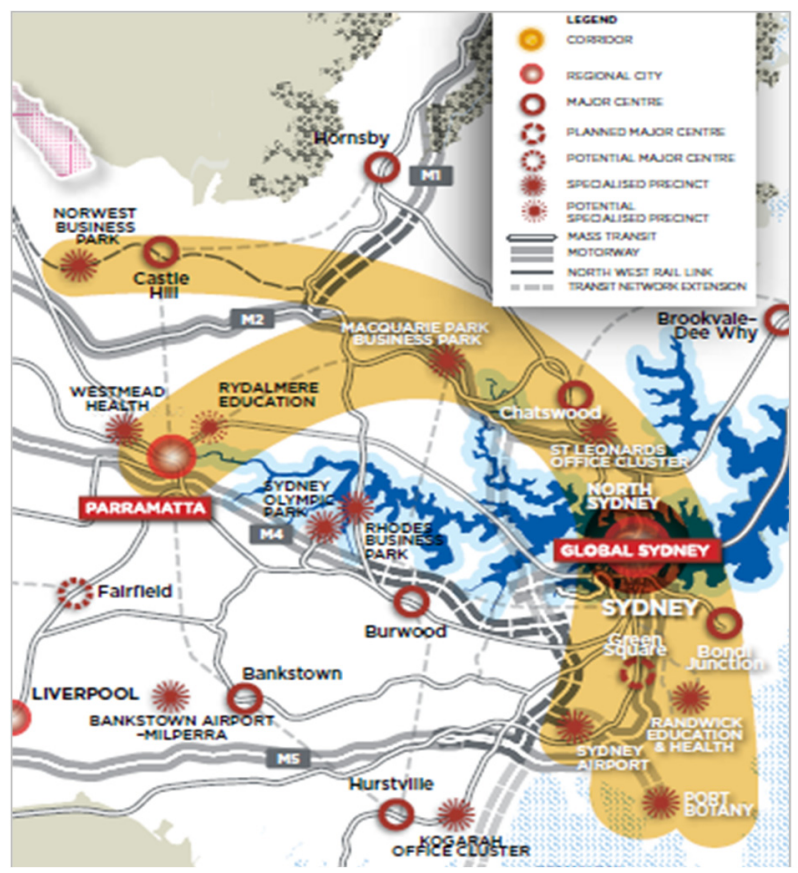

Figure 2: $\quad$ Draft Sydney Metropolitan Strategy 2013 showing Green Square as a planned major centre [2].

This paper documents the challenges and constraints the city has faced in developing the Green Square Town Centre from an older style industrial area into a modern, mixed-residential precinct of high amenity and opportunity. 


\section{A short history of Green Square}

Green Square takes its name from a small park named in 1938 to honour Frederick Green, a Member of State Parliament and tireless promoter of local industry and jobs who was a mayor of Alexandria [3].

Traditional owners of this land were the Gadigal people of the Eora nation. The Green Square area probably formed the southern extent of their territory. They were attracted to the fresh water creeks and wetlands and abundant food.

Following European settlement, Green Square emerged as a market garden area due to its water supply that formed part of the south Sydney wetland corridor.

Its industrial heritage dates back to 1815 with the arrival of grain mills and wool-washing, tanneries and fur traders, who were also attracted to the area's reliable water supply. The area was also used as a source of water for the growing city, and was diverted into tunnels and dams.

Throughout the nineteenth century, industry continued to grow and the first industrial suburb, known as the "Cooper Estate", contained brickworks, candle and soap factories, tanneries, breweries and wool-washing firms, schools and churches. By 1869, the environment had changed radically - streams had almost ceased to flow, and the natural environment suffered.

The area's industrial landscape was well established by the late 19th century with joiners, founders and engineers. Residential subdivision also began to occur and improved roads and transport meant that goods could be delivered to the ports much faster. In consequence, expansive and often purpose-built factories began to fill the landscape.

By early 1900, the Green Square area (or Alexandria) had become a manufacturing powerhouse and was at the time, 'the largest industrial municipality in Australia' with over 500 factories and 22,238 workers [4].

Mechanisation and expansion reached its zenith in the 1950s, as industrial decentralisation resulted in the movement of heavy industry away from South Sydney. The downturn in secondary industry since the 1970s furthered this process of decline. By the 1960s, Green Square emerged as an area for waste processing. Waverley and Woollahra councils were permitted to build the huge Waterloo Incinerator over the infilled site of Waterloo Dam, which now forms part of the Green Square Town Centre. Technological change and the expansion of service industries have brought different kinds of industry to the area as manufacturing began to decline.

The Sydney Olympics in 2000 also resulted in improved access to the area with construction of a rail link from the city to the airport, with a station at Green Square and the Eastern Distributor road link. These improved access from the airport to the city and encouraged a focus from government on urban renewal.

The predominant land use is now light industrial, with service depots, warehousing and distribution and motor showrooms and offices. Development is generally large in footprint and up to two storeys high. Although still dominated by manufacturing, the newer industries include motor showrooms, high tech industry, wholesaling and storage. 
There has also been a more recent rise of creative industries with warehouse conversions to create unique work environments for designers, artists and hightech manufacturing. Large-scale residential redevelopment is also occurring in the broader Green Square area in Waterloo, Rosebery and Zetland, which is mixed in with older style workers cottages and terraces.

\section{Challenges}

This section discusses the challenges which the City of Sydney and other parties faced redeveloping Green Square Town Centre and surrounding area. This area is now finally beginning to emerge as an area of sustainable urban renewal in inner Sydney, some 20 years after the town centre was originally conceived.

\subsection{Land ownership}

A major constraint to broad-scale redevelopment of established inner city areas is the existing property ownerships fragmented over years of land use occupation and business operation. A common constraint affecting redevelopment is that only some of the land owners are willing to participate. Proposed plans often require major lot amalgamations to foster a desirable urban design and planning outcome. Achieving short-term redevelopment for a planned major centre is hugely challenging as it takes time for landowners to embrace the plan and then arrange financial dealings which are agreeable for each landowner and business operator.

Green Square still has diverse lot sizes and property ownership arrangements, from large sites over one hectare to small sites of $200 \mathrm{~m}^{2}$. The area also has many irregular shaped sites largely due to the existing road pattern, which also can affect subdivision and redevelopment.

The South Sydney Development Corporation was formed by state government to plan and promote urban renewal at Green Square but was underfunded to achieve this before any major infrastructure was provided in the area.

The first decision to overcome the land ownership constraint was to locate Green Square station directly opposite a large area (five hectares) of exgovernment land. This became the logical place to locate the town centre right next to major transport corridors. Urban Growth NSW, a state government land development corporation, was later brought in to consolidate the government lands. They now control almost half of the lands within the town centre including the Green Square plaza and primary shopping strip.

A public infrastructure strategy was also developed by the City of Sydney, Urban Growth and land owner input.

The City of Sydney has entered into a planning agreement with developers to deliver infrastructure including dedication of land to Council for community purposes. The planning agreement includes developer contributions and/or works in kind for infrastructure over time. The city is effectively forward funding much of the upfront infrastructure costs. These agreements will provide around $\$ 100$ million of additional funding over the next 10 years for the town centre. 


\subsection{Infrastructure funding}

Infrastructure funding for urban redevelopment has been a constant challenge for government, whether it is for fringe or infill development. Various mechanisms have been used but the main funding strategy is from government to rely on contributions by developers for local infrastructure.

Typical measures have included developer contributions, State government infrastructure contributions; upfront infrastructure funding by a developer to obtain approval by government for land release; and upfront government financing with payback option for community facilities and land dedications. Other standard measures include build-own-operate and transfer of infrastructure to public use, public partnerships, and additional recurrent charges for utilities.

Infrastructure provision is particularly difficult for long-term redevelopment areas such as Green Square, which have an extended development period. These cannot be funded over the long-term due to the high rates of return required on capital by developers.

Upfront infrastructure funding for long-term development areas is also critical. This ensures that the financiers of proposed major development are confident of appropriate infrastructure to attract investment.

Green Square was no different and the area needed substantial funding for utility infrastructure such as water, power and drainage, as well as for roads and open space and community facilities. The city was committed to providing the best infrastructure outcome for Green Square and in 2006 developed an infrastructure strategy for the town centre [5]. This stated:

"infrastructure must be planned, designed and constructed in an integrated and coordinated way. It should be funded in an equitable manner, reflecting the overall benefit resulting from the scheme."

The strategy was based on the previous zoning plan and updated 2006 master plan which proposed a gross floor area for commercial and residential and an anticipated population. It also proposed that roads and a local park and plaza would be obtained by dedication. Importantly the strategy focused on the implementation of major infrastructure prior to the redevelopment of the lands for residential and commercial purposes.

As there was no available federal or state government funding, a new financing approach was needed to encourage redevelopment. Critical to the infrastructure strategy was the development rights scheme which allowed land to be released for development (rezoned) when a planning agreement between the city and the developer was established. This committed the developer to provide contributions to the essential services (such as roads and public domain) and/or land dedications and public domain improvements. This method was innovative and preceded a lot of current practice for government working with the private sector on land release, as it captured an additional level of contributions attributable to the special value of the town centre lands.

Ultimately the city has committed the upfront funding for the infrastructure and will recoup the developer contributions over time as the land is redeveloped. This 
again provided developer and market confidence for the town centre to develop. Figure 3 shows the location of the key infrastructure projects that the city is delivering in the town centre.

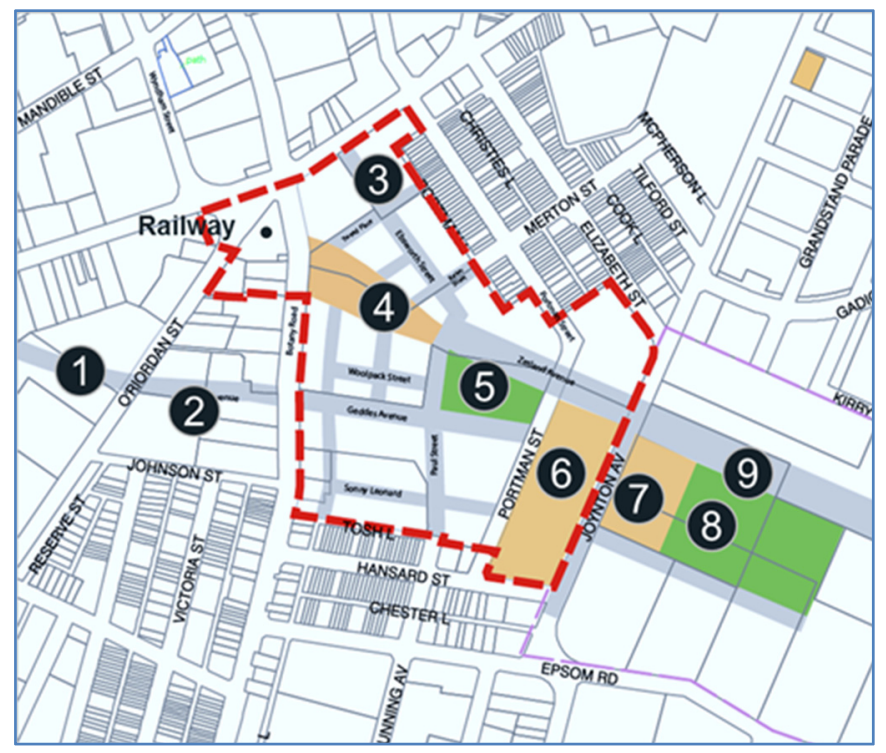

Figure 3: City of Sydney proposed infrastructure works for the Green Square Town Centre [6].

\subsection{Key infrastructure projects}

1. A major $2.4 \mathrm{~km}$ storm water drain to address high-risk flooding

2. A western transport route to provide better connections to the town centre

3. New roads and utilities with a much finer grain

4. A large plaza which will become the place of social interaction and gathering for community and cultural events and new underground library

5. A new passive recreation park as the green lungs of the town centre incorporating public art

6. Disused heritage buildings which will become the place of creative and community activities and location for sustainable water reuse

7. A new aquatic Centre as an active recreation space and centre for health and wellbeing

8. New active open space area for sporting activity

9. An eastern transit corridor to provide boulevard access to town centre and the Sydney CBD 


\subsection{Access and mobility}

Green Square exists at the junction of three main north-south roads that primarily connect the city to the airport, Port Botany and the industrial areas of Mascot and Alexandria. There are very few connecting major east-west roads which impacts on the ability of the town centre to fully connect with surrounding areas such as Sydney's eastern suburbs and inner west.

The predominance of north-south roads and the location of the proposed town centre mean that the area has been a place you travel through rather than a destination in itself. The road pattern provides a real challenge for government to create a new town centre and a sense of place and arrival.

The completion of the Eastern Distributor road link in 2000 provided an expressway access between the city centre and the Airport bypassing Green Square. However the existing local and regional road network continually suffers from congestion, traffic migration or "rat running", poor connections to the west and east and significant heavy vehicle use of local streets. The pedestrian legibility of the area is poor as many intersections lack pedestrian crossings, even at Green Square station. There are also few connecting east and west roads to promote effective walkability and optimum cycle use.

By placing town centre adjacent to the station but slightly offset from the main arterial road (Botany Road), it provided the basis to develop a town centre plan to easily link future residential and commercial areas to the station interchange. It also prevents existing through traffic from penetrating into the core of the town centre.

The road pattern is planned on a layout of connecting local streets and shared ways around a town plaza. This fosters a travel environment of low speeds and high visibility of pedestrians and cyclists. The town centre road design informs the driver that this is a shared environment of equal access for pedestrians, cyclists and vehicles. The premise of "the car as a guest in the town centre" is strongly reinforced through pavement design, landscaping, and the placement of pedestrian crossings, widened footpaths and restricted vehicle areas. The city is also promoting sustainable transport planning under the Sustainable Sydney 2030 direction of "Connecting Green Square" [7].

This involves:

- A light rail and new transit corridor to connect to town centre and station to the city via the planning precincts Victoria Park, Epsom Park, Danks and suburbs of Waterloo and Surry Hills;

- Provision of new bike lanes to connect Green Square with the city, towards the east and inner west and south towards the airport as well as bike parking requirements at developments and Green Square station;

- New bus routes to connect the city and surrounding suburbs;

- A series of connected streets and roads with a high quality public domain that allow for easy pedestrian access;

- A new western connector road which will provide for better access to the town centre for public transport; and 
- Setting maximum vehicle car parking rates at residential development sites to control excessive car use.

This transport planning approach is important to providing an accessible pedestrian friendly town centre. The city is committed to reducing car dominance and dependency for the new emerging centre and improving the poor pedestrian and cycle environment that currently exist.

\subsection{Flooding}

Green Square as a former wetland has a long history of flooding and inadequate drainage infrastructure. The floods in 2012 resulted in considerable damage to public and private property and people were rescued from their cars. Flooding is therefore a major constraint to creation of the town centre. This was a challenge that could not be resolved by on-site water detention solutions but needed a major, catchment-wide solution.

Local government is responsible for developing floodplain risk management strategies. The need for a major upgrade of water infrastructure to promote town centre development exposed the need for a partnership between state and local government. Furthermore, many of the drainage assets which needed to be upgraded were owned by the state government.

Major infrastructure upgrades were required to safeguard flood-prone areas from flooding to achieve optimum development. Without major investment flood risk would not be mitigated.

The state water provider (Sydney Water Corporation) would not support the development of a town centre without a comprehensive flooding solution. To facilitate state government involvement, the city commissioned a number of flood studies to seek a solution to the flooding. A number of options were considered including broadscale detention, upgrade to existing drainage culverts and major new drainage system.

In 2014, the city and Sydney Water Corporation reached an agreement to jointly fund a $2.4 \mathrm{~km}$ drainage culvert that captures flood waters flowing through the town centre. The drain will be completed in 2017 and will help unlock the planning vision for the town centre and surrounds by overcoming a major planning impediment in the town centre.

\subsection{The station access fee}

The new rail line to the airport via Green Square station provided a major transport boost for the area when it opened in 2000 as the area was beginning to attract developer interest. However the line is privately operated and Green Square Station contained a station access fee on top of a regular train fare to fund the construction of the rail line and made patronage unappealing.

In early 2011, the NSW Government removed the station access fee at Mascot and Green Square stations. This resulted in a 75 percent increase in daily commuter use of these stations. 
Whilst the station access fee was not the main impediment to achieving shortterm urban renewal, it provided an additional hurdle for investors and developers to attract residents and workers into the area and promote the town centre.

\subsection{Developing Green Square town centre as a place}

The city has developed a place making strategy for the town centre to create a strong sense of place and community for residents. From a design perspective, an interconnected street pattern will achieve pedestrian safety and accessibility. From a cultural perspective a series of public spaces will become the key gathering spaces in the town centre and place for events. A significant public art investment will support the cultural growth of the town centre. From a digital perspective, public WiFi will allow a connection to the world from a local place.

Pivotal to the place making strategy, is the delivery of the community infrastructure and assets by the city (refer to Figure 3 ). These projects will provide a high level of amenity for future residents, workers and visitors. Images of the proposed library plaza development and aquatic centre and park are provided at Figures 4 and 5.

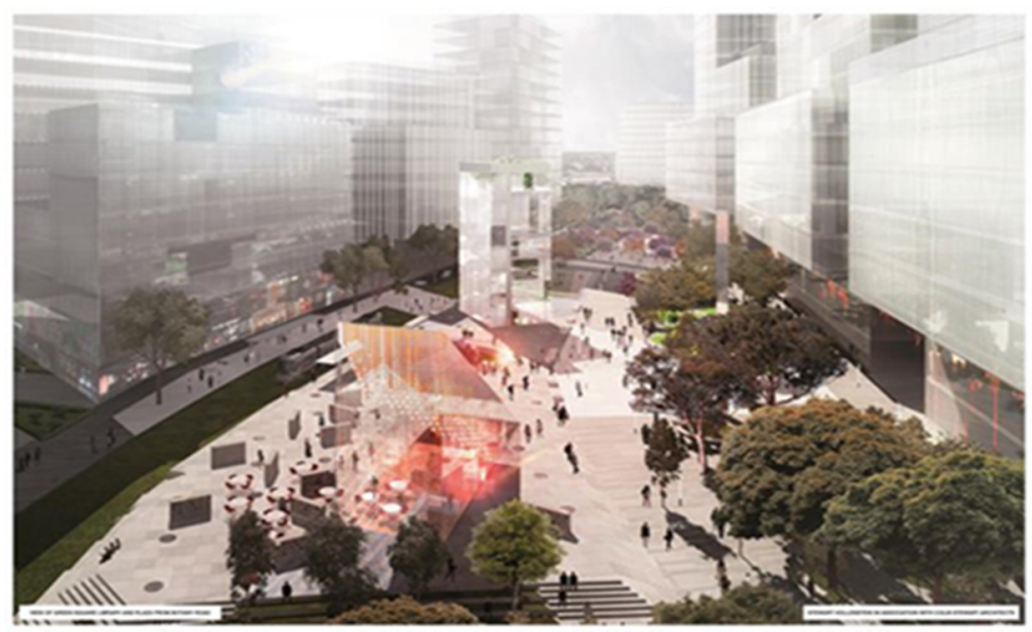

Figure 4: The proposed Green Square Library and Plaza [8].

\subsection{Green Square: a response to climate change}

The world is facing continual climate change pressures which are affecting our resources and ultimately how we live and work. In 2010, the city released Sustainable Sydney 2030 [10] as a city wide attempt to reduce greenhouse gas emissions beyond on any national target. The strategy also aims to reduce water and waste demands. 


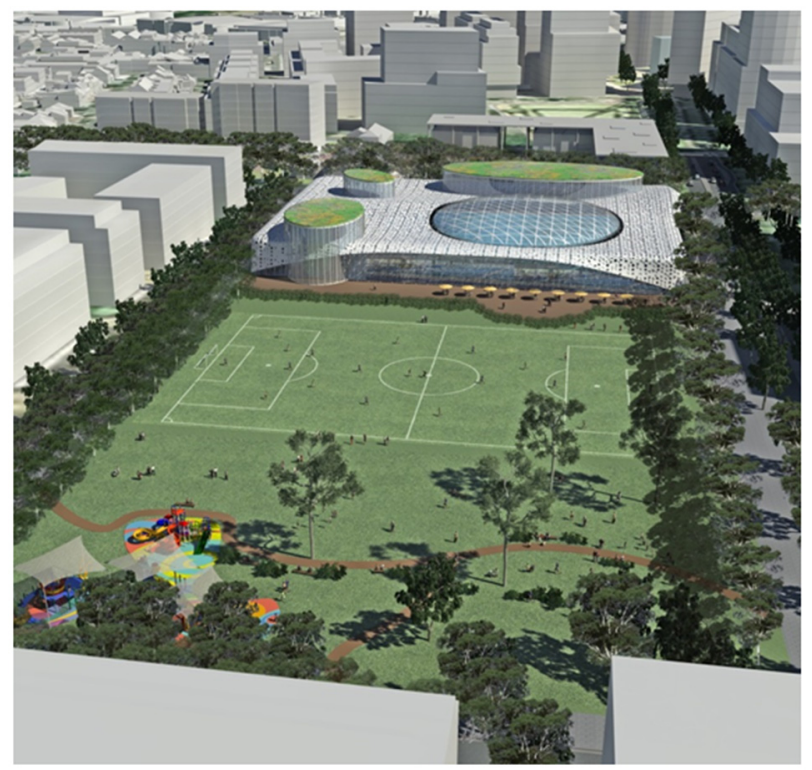

Figure 5: The proposed Green Square Aquatic Centre and Gunyama Park [9].

This was premised on a vision of Sydney being "Green, Global and Connected". Sustainable Sydney 2030 also contained 10 strategic directions and project ideas covering cultural and community, access, economic and service related issues. The strategy provided the opportunity to directly respond to climate change by moving away from the standard approach to land use planning and infrastructure provision.

Sustainable Sydney 2030 embraced the Green Square town centre as a chance for the city to implement precinct based systems for energy and water, which

- A water re-use facility which allows for reuse of storm water (grey water) for use at residential and commercial buildings; and

- Highly efficient air conditioning systems.

\section{Conclusions}

This paper has identified the challenges faced by government in developing a vibrant and new town centre in an existing city. The paper identifies that a range of funding measures, strategic partnerships and principles had to be developed to overcome these challenges.

The City of Sydney's adopted best practice solutions such as civil and social infrastructure planning, upfront infrastructure funding via planning agreements and working closely with key state government agencies are pivotal in initiating Green Square Town Centre. These initiatives will promote the Town Centre that connects with local community life and ensures that Green Square makes a major contribution to a sustainable city. The key points are summarised below: 
- Developing a new town centre in an old industrial area is highly constrained due to physical constraints, land ownership and new infrastructure requirements;

- Partnerships are critical to addressing constraints and building a shared vision between governments (local and state) and between private developers and public authorities;

- All constraints must be addressed to an appropriate risk threshold to gain commitment of stakeholders and financiers;

- Upfront public infrastructure is a major selling point for developers as it reduces risk and provides confidence in the market;

- Coordinated place making strategies need to be implemented across public and private domains to create activation, identity and sustainability for the community in a new town centre;

- A new town centre to support the local community must attract investors and visitors to be economically and socially sustainable; and

- New technologies and ideas must be embraced to make places relevant and keep them sustainable.

\section{Acknowledgement}

Note: the views expressed in this paper do not necessarily reflect the views of the City of Sydney Council.

\section{References}

[1] Expedia, www.expedia.com.au/Sydney

[2] NSW Department of Planning \& Infrastructure, Draft Metropolitan Plan for Sydney 2031, Summary, pg 9, March 2013

[3] Wikipedia, http://en.wikipedia.org/wiki/Green_Square,_New_South_Wales

[4] City of Sydney, Green Square Library and Plaza Design Competition Brief, Appendix 4, 2012

[5] City of Sydney, Green Square Infrastructure Strategy, pp 1-22, 2006

[6] Woodbury, K, Presentation to the Sydney Business Chamber, Slide 10, 2014

[7] City of Sydney, Sustainable Sydney 2030, pg 168, 2009

[8] Stewart Hollestein Consultants, Library and Plaza Competition Design Report, 2014

[9] Woodbury, K, Presentation to the Sydney Business Chamber, Slide 14, 2014

[10] City of Sydney, Sustainable Sydney 2030, pg 189, 2009 